\title{
TINJAUAN SADD DZARI'AH TERHADAP PROBLEMATIKA HUKUM MENIKAHI WANITA AHLI KITAB DALAM HUKUM POSITIF
}

\section{DZARI'AH SADD REVIEW ON LEGAL PROBLEMATICS MARRIED ANEXPERTS WOMAN IN POSITIVE LAW}

\author{
Nur Azizah \\ Program Magister Fakultas Syari'ah dan Hukum UIN Sunan Kalijaga \\ Jalan Laksda Adisucipto, Caturtunggal, Depok, Kabupaten Sleman, Daerah \\ Istimewa Yogyakarta 55281 \\ E-Mail: nurazizahhutagalungdo@gmail.com
}

\begin{abstract}
Halal marriage as a category makruh marriage between Muslim men with women experts of the book. In addition, the legal status of different religious marriages in Indonesia still reap the polemic and does not strictly prohibit. For the occurrence of different religious weddings are still open gaps or opportunities of occurrence, including marriage of Muslim men with female scribes even among Muslim women with men of the book. So with the second law of origin that provides an opportunity for the marriage of the woman of the book with the Muslim man, the researcher uses a review of Sadd Dzari'ah where in origin the legal action may be prohibited by the concern because of the great potential of giving negative impact (mafsadat).

Keywords: Sadd Dzari'ah, women scribe and positive law
\end{abstract}

\begin{abstract}
ABSTRAK
Pernikahan halal sebagai kategori makruh pernikahan antara lelaki muslim dengan wanita ahli kitab. Selain itu, status hukum pernikahan beda agama di Indonesia masih menuai polemik dan tidak melarang secara tegas. Untuk terjadinya pernikahan beda agama masih terbuka celah atau peluang terjadinya, termasuk pula pernikahan pria muslim dengan wanita ahli kitab bahkan antara wanita Islam dengan pria ahli kitab. Maka dengan adanya kedua hukum asal yang memberikan peluang untuk terjadinya pernikahan wanita ahli kitab dengan pria muslim tersebut, peneliti menggunakan tinjauan Sadd Dzari'ah dimana pada asalnya susuatu tindakan hukumnya boleh menjadi terlarang dengan adanya kekhawatiran sebab berpotensi besar melahirkan dampak negatif (mafsadat).

Kata Kunci: Sadd Dzari'ah, wanita ahli kitab dan hukum positif.
\end{abstract}




\section{Jurnal Ilmiah Al-Syir'ah Vol. 16 No. 1 Tahun 2018 Institut Agama Islam Negeri (IAIN Manado)}

Perkawinan adalah perbuatan hukum yang berkaitan erat dengan keperdataan Islam. Perkawinan sudah menjadi kajian yang amat tua namun selalu menimbulkan masalah kontemporer yang perlu dikaji lebih dalam lagi terlebih perkawinan bukan hanya menjadi kajian hukum Islam klasik, namun sudah masuk pada ranah hukum positif. Hukum Perkawinan di Indonesia diatur di dalam Undang-undang Perkawinan atau bisa disebut UU No. 1 Tahun 1974, Kompilasi Hukum Islam, PP. No. 9 Tahun 1975, UU No. 23 Tahun 2006 tentang Administrasi Kependudukan, dan masih banyak aturan hukum lainnya.

Bebeberapa Lembaga hukum yang berwenang dalam masalah perkawinan serta aturan hukumnya adalah Pengadilan Negeri dan Pengadilan Agama baik tingkat I maupun tingkat II, Mahkamah Agung, Mahkamah Konstitusi. Sampai saat ini perkawinan beda agama menjadi suatu topik persoalan hukum yang hangat untuk diperbincangkan, hal ini berkenaan dengan perkembangan hukum yang menimbulkan peraturan yang terlihat kontroversial serta penanganan dari lembaga-lembaga hukum yang berujung pada putusan yang simpang siur. Dapat kita lihat di dalam Undang-Undang No. 1 Tahun 1974 dan Inpres No. 1 Tahun 1991 (KHI) terdapat perbedaan yang signifikan, di mana UUP tidak mencantumkan perbedaan agama (murtad) sebagai alasan perceraian sedangkan KHI menyebutkan bahwa murtad adalah salah satu alasan perceraian meskipun ada penjelasan bahwa kemurtadan sebagai alasan perceraian hanya diterima apabila hal tersebut menimbulkan perselisihan dalam rumah tangga.

KHI dan UU No. 1 Tahun 1974 melarang perkawinan beda agama, namun pasal lain di dalam UUP perkawinan memberikan jalan keluar untuk melegalkan perkawinan beda agama secara terang-tengan di Luar Negeri. Pasal yang mengatur tentang larangan perkawinan beda agama pernah diajukan ke Mahkamah Konstitusi untuk dilakukan uji materi untuk kemudian dihapuskan, 
MK menolak dengan tegas. Namun yang mengherankan adalah berbanding terbalik dengan Mahkamah Agung yang memberikan amar putusan kebolahan perkawinan beda agama di dalam putusan No. 1400 K/Pdt/1986. Putusan ini menerangkan bahwa kebolehan pencatatan perkawinan di dalam UU No. 23 Tahun 2006 (ADMINDUK) berlaku juga untuk pasangan yang berbeda agama.

Sebenarnya fenomena nikah beda agama yakni antara laki-laki muslim dan wanita ahli kitab sudah lebih dulu dikaji di dalam Hukum Islam yakni Al-Quran, Hadits, serta penjelasan para ulama mazhab terkemukan hingga ulama kontemporer, hukumnyapun telah jelas disebutkan boleh dalam kategori makruh menurut jumhur. Berhubung hukum Islam yang dimaksud sebelumnya cendrung membolehkan perkawinan beda agama bersesuaian dengan pertimbanganpertimbangan hukum dan kondisi. Namun melihat perkembangan zaman di masa IPTEK yang merajalela serta zaman yang serba hiruk pikuk dan penuh masalahmasalah kontemporer yang semakin rumit,penulis menggunakan metode istinbat hukum Sadd Dzari'at untuk meninjau problematika aturan hukum perkawinan beda agama di di Indonesia. Namun peneliti hanya mengkhususkan tinjauan Sadd Dzari'ah pada perkawinan beda agama yakni antara laki-laki muslim dengan wanita Nasrani atau Yahudi.

Metode istinbat hukum ini dapat digunakan untuk menganalisis sebuah peristiwa hukum yang sebelumnya diperbolehkan, kemudian berubah menjadi dilarang dengan mempertimbangkan mafsadat-mafsadat dan kerugian yang akan timbul apabila tetap diperbolehkan. Sebab pertimbangan inilah demi menjaga tujuan hukum Islam maka metode Sadd Dzari'at sangat tepat.

Melihat putusan dari beberapa lembaga hukum yang nampak simpang siur dan juga alasan perceraian yang termaktub di dalam UUP dan KHI tentang murtad tidak secara tegas diatur bahkan dapat dikatakan tidak mengikat sehingga 
mengakibatkan adanya celah-celah hukum atau lubang-lubang hukum yang dengan mudah dilalui. Ditambah adanya yurispridensi MA yang berimplikasi pada UU ADMINDUK, maka peneliti tertarik untuk mengkaji secara jelas dengan cara menempatkan metode Sadd Dzari'at sebagai penengah.

\section{PROBLEMATIKA HUKUM MENIKAHI WANITA AHLI KITAB DALAM HUKUM ISLAM}

Dalam Islam orang yang menganut kepercayaan yakni Nasrani (kristen) disebut sebagai ahli kitab. Sudah menjadi kesepakatan ulama bahwa tern ahl al Kitab menunjuk kepada dua komunitas penganut agama samawi sebelum Islam yaitu Yahudi dan Nashrani (Mardani, 2011: 82). Pada masa Rasulullah SAW dan para sahabatnya, term ahl al Kitab selalu digunakan untuk menunjuk kepada komunitas agama Yahudi dan Nashrani. Selain komunitas itu, mereka tidak menyebutnya sebagai ahl al Kitab. Kaum majusi misalnya, meskipun pasa masa Nabi dan para sahabat sudah dikenal, tetapi mereka tidak disebut sebagai ahl al Kitab. Meskipun demikian, Rasulullah SAW tetap memerintahkan supaya memperlakukan mereka seperti halnya ahl al-Kitab.

Ayat yang menyinggung tentang ahl al Kitab dalam Al-Quran sangat banyak, yakni 125 kali (Tahir Mahmood, 1987: 99-100). Ada satu ayat yang menunjukkan hukum kebolehan menikahi wanita ahl al-Kitab yakni kristen (Yahudi):

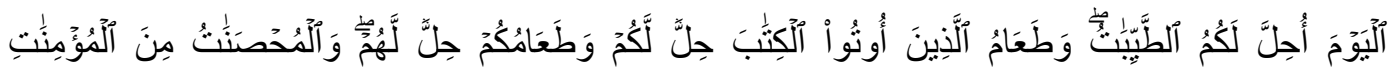

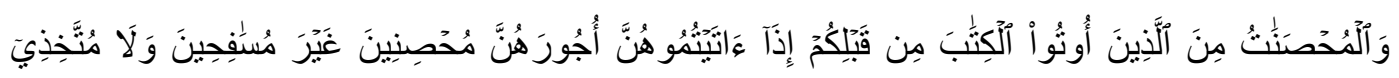

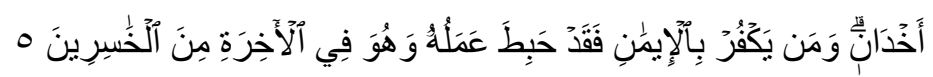




\section{Jurnal Ilmiah Al-Syir'ah Vol. 16 No. 1 Tahun 2018 Institut Agama Islam Negeri (IAIN Manado)}

"Pada hari ini dihalalkan bagimu yang baik-baik. Makanan (sembelihan) orangorang yang diberi Al Kitab itu halal bagimu, dan makanan kamu halal (pula) bagi mereka. (Dan dihalalkan mangawini) wanita yang menjaga kehormatan diantara wanita-wanita yang beriman dan wanita-wanita yang menjaga kehormatan di antara orang-orang yang diberi Al Kitab sebelum kamu, bila kamu telah membayar mas kawin mereka dengan maksud menikahinya, tidak dengan maksud berzina dan tidak (pula) menjadikannya gundik-gundik. Barangsiapa yang kafir sesudah beriman (tidak menerima hukum-hukum Islam) maka hapuslah amalannya dan ia di hari kiamat termasuk orang-orang merugi”. (QS. AlMaidah/5: 5)

Namun Menurut pendapat Abdullah bin Umar, Syi'ah Imamiyah ( Amiur Nuruddin dan Azhar Akmal Tarigan, 2004: 17), dan Ali al Shabuni, (Sayuti Thalib, 1985: 37-40) bahwa menikahi wanita ahl al Kitab haram hukumnya. Mereka berdalil kepada QS. Al-baqarah/2: 221; dan janganlah kamu menikahi perempuan-perempuan musyrikah hingga mereka beriman, QS. AlMumtahanah/60:10; dan janganlah kamu berpegang (yakni ceraikanlah) perempuan-perempuan kafir yang telah kamu nikahi, serta hadist Nabi yang berbunyi: bahwa perkawinan yang baik adalah sama dengan setengah iman dan hadist : bahwa anak lahir dalam keadaan fitrah (suci) hanya orang tuanyalah menjadikan mereka Yahudi, Nashrani, dan penganut Zoroaster (Mardani, 2011:84)

Ibnu Umar ketika ditanya tentang seorang laki-laki yang menikahi wanita Nashrani dan Yahudi justru mengatakan bahwa ahlul kitab termasuk musyrik seraya mengatakan: (As-Sayyid Sabiq, 1983: 90)

Allah mengharamkan menikahi wanita-wanita musyrik, saya tidak mengatahui kemusyrikan yang lebih besar dari keyakinan seseorang yang 
mengatakan bahwa Tuhannya adalah Isa atau salah seorang dari hamba-hamba Allah.

Berbeda halnya dengan pandangan mayoritas ulama, sahabat, Tabi'in, ulama salaf, dan ulama kontemporer, sebagian besar mazhab ja'fariyah, bahwa menikahi menikahi perempuan nashrani halal hukumnya akan tetapi makruh. Mereka berdalil pada Al-maidah ayat 5 yang turun setelah Al-Baqarah.(Mardani, 2011: 83) Selain itu, mereka juga brargumentasi kepada sejarah. Sejarah telah menunjukkan, bahwa beberapa sahabat Nabi pernah menikahi perempuan ahl al kitab, seperti Usman bin Affan menikah dengan Nailah binti Al-Farafisah yang beragama Nashrani, Talhah menikah dengan wanita Yahudi, Ibnu Abbas, Jabir, dan Huzaifah (Mardani, 2011:83)

Berkaitan dengan kasus sahabat bernama Huzaifah, Umar bin AlKhaththab pernah meminta Huzaifah untuk menceraikannya, kemudian Huzaifah bertanya kepada Umar; “Apakah engkau mau bersaksi bahwa nikah dengan kitabiyyah adalah haram?" Umar menjawab: "Itu fitnah" (Wahbah az-Zuhaili, 1989:154). Dari jawaban Umar tersebut menunjukkan bahwa menikahi kabiyyah tidak haram hanya saja pernikahan ini dilarang karena berbahaya dan dikhawatirkan akan menimbulkan mafsadat.

\section{PROBLEMATIKA ATURAN HUKUM PERKAWINAN BEDA AGAMA DI INDONESIA}

Indonesia adalah negara Agama bukan negara Islam, dimana di negara ini mencantumkan 6 agama sebagai agama yang diakui di Indonesia,yakni Islam, Kristen Protestan, Kristen Katolik, Hindu, Buddha, Konghuchu yang baru-baru ini diakui di Indonesia. Ada terdapat beberapa peraturan hukum di Indonesia yang menyinggung atau bahkan mengatur secara jelas tentang perkawinan beda agama. Negara Indonesia dikenal dengan aturan hukumnya yang melarang adanya 
perkawinan beda agama, namun pada realitasnya terdapat aturan hukum dan fenomena sosial yang terjadi di lapangan terdapat kejanggalan-kejanggalan yang perlu diteliti lebih lanjut.

Namun penulis tidak membahas tentang apa yang terjadi di lapangan, penulis hanya membahas terkait hukum-hukum yang mengatur tentang perkawinan beda agama di Indonesia. Adapun aturan-aturan hukum tentang perkawinan beda agama di Indonesia yang akan dibahas adalah:

\section{PASAL-PASAL TENTANG LARANGAN PERKAWINAN BEDA AGAMA DI INDONESIA}

Adapun pasal-pasal yang melarang terjadinya perkawinan beda agama adalah:

Pasal 40 (c) KHI: Dilarang melangsungkan perkawinan antara seorang pria denagn seorang wanita karena keadaan tertentu: (c) seorang wanita yang tidak beragama islam.

Pasal 44 KHI: Seorang wanita Islam dilarang melangsungkan perkawinan dengan seorang pria yang tidak beragama Islam.

Pasal ini kemudian dikuatkan dengan Undang-Undang No 1 Tahun 1974, yaitu:

Pasal 2 (1) menyebutkan: perkawinan adalah sah, apabila dilakukan menurut hukum masing-masing agamanya dan kepercayaannya itu. Di samping itu merujuk pasal 8 (f), yakni: Perkawinan dilarang antara dua orang yang : (f) mempunyai hubungan yang oleh agamanya atau peraturan lain berlaku, dilarang kawin. (UU No. 1 Tahun 1974)

MUI indonesia turut serta dalam memberikan aturan hukum tentang kawin beda agama dengan fatwa hukum, di mana isi dari fatwa itu adalah Keputusan Fatwa Majelis Ulam Indonesia Nomor: 4/MUNAS VII/MUI/8/2005 Tentang Perkawinan Beda Agama yaitu Perkawinan beda agama adalah haram dan tidak 
sah; Perkawinan laki-laki muslim dengan perempuan ahli kitab, menurut qaul mu'tamad adalah haram dan tidak sah (Fatwa Majelis MUI No: 4/MUNAS VII/MUI/8/2005).

Pendapat yang sering dianut oleh para hakim Pengadilan Agama menganggap tidak boleh dilakukan kawin lintas agama, baik antara laki-laki muslim dengan perempuan nonmuslim atau sebaliknya. Pernah pula atas pemikiran dengan berdalihkan hak azasi manusia dan kebebasan beragama ada tuntutan pada Mahkamah Konstitusi yakni mengajukan pasal-pasal larangan perkawinan beda agama di Indonesia untuk kemudian dihapuskan, namun atas beberapa pertimbangan MK menolak dengan tegas tentang tuntutan penghapusan pasal larangan perkawian.(Putusan MK No. 68/PUU-XII/2014)

Namun bukan itu yang menjadi permasalahan pokok yang perlu dibahas oleh penulis dalam jurnal ini. yang menjadi problem atau masalah adalah terdapat kejanggalan-kejanggalan hukum yang menurut penulis berdampak pada timbulnya kontroversial antara lembaga hukum di Indonesia dan antara pasalpasal yang berlaku di Indonesia. Problematika hukum ini mempengaruhi status hukum perkawinan beda agama di Indonesia.

\section{PERKAWINAN BEDA AGAMA DI DALAM KHI DAN UU PERKAWINAN}

Sudah diketahui sebelumnya di atas bahwa terdapat pasal-pasal KHI dan UUP yang melarang perkawinan beda agama. Namun yang membuat bingung adalah ada beberapa pasal yang secara langsung maupun tidak langsung memberi ruang untuk terlaksananya perkawinan beda agama ini. hal itu dapat kita lihat pada pasal 56 UU No. 1 Tahun 1974 secara gamblang menunjukkan kebolehan itu dan secara tersiratnya adalah aturan hukum tentang sebab-sebab perceraian. 


\section{Jurnal Ilmiah Al-Syir'ah Vol. 16 No. 1 Tahun 2018 Institut Agama Islam Negeri (IAIN Manado)}

Dalam pasal 56 ayat 1 UU No. 1 Tahun 1974 disebutkan bahwa perkawinan yang dilangsungkan di luar Indonesia antara dua orang warga negara Indonesia atau seorang warga negara Indonesia dengan warga negara asing adalah sah bila mana dilakukan menurut hukum yang berlaku di negara di mana perkawinan itu dilangsungkan dan bagi warga negara Indonesia tidak melanggar ketentuan-ketentuan undang-undang ini. Pada pasal 56 (2) mengatur tentang pendaftarannya setiba di Indonesia, yaitu dalam waktu 1 (satu) tahun setelah suami istri itu kembali di wilayah Indonesia (Sri Wahyuni, 2016:175) Jelas ini memberi angin segar bagi orang-orang yang memang berkehendak untuk melakukan nikah beda agama. Peraturan Undang-Undang ini dapat dikatakan sebagai celah hukum atau malah solusi hukum untuk keluar dari pasal-pasal pelarangan perkawinan beda agama.

Meskipun di dalam pasal 56 (2) juga disyaratkan bahwa perkawinan tersebut tidak melanggar ketentuan UUP, sebagaimana pula di sebutkan pada pasal 1 ayat 2 bahwa perkawinan sah apabila dilangsungkan menurut ketentuan agama masing-masing, pada nyatanya perkawinan beda agama yang dilakukan warga Indonesia di Luar Negeri dapat melegalkan perkawinan perkawinan tersebut. Hal ini berdalil pada pasal 56 UUP dan pada realitanya negara memang mengakui perkawinan ini dan bahkan dikuatkan dengan melakukan pendaftaran perkawinan di Kantor Pencatatan Sipil, hal ini dapat kita lihat pada Peraturan Menteri Agama Republik Indonesia No. 1 Tahun 1994 tentang Pendaftaran Surat Bukti Perkawinan Warga Negara Indonesia yang dilangsungkan di Luar Negeri.

Pasal 1 Bagi warga negara Indonesia yang beragama Islam yang telah melakukan perkawinan di luar negeri sebagaimana dimaksud pasal 56 ayat (2) Undang-Undang No.1 Tahun 1974, paling lambat satu tahun setelah suami-istri kembali di wilayah Indonesia, surat bukti perkawinannya harus didaftarkan pada 


\section{Jurnal Ilmiah Al-Syir'ah Vol. 16 No. 1 Tahun 2018 \\ Institut Agama Islam Negeri (IAIN Manado)}

Kantor Urusan Agama Kecamatan yang mewilayahi tempat tinggal mereka (Peraturan Menteri Agama RI No. 1 Tahun 1994).

Kemudian yang menjadi titik persoalan selanjutnya adalah tidak ada tercantum di dalam UU No 1 Tahun 1974 tentang Status Perkawinan yang salah satu murtad, bahkan Kompilasi Hukum Islam hanya menyebutkan bahwa murtad adalah salah satu sebab-sebab (alasan) perceraian itupun apabila kemurtadan ini menimbulkan perselisihan atau pertengkaran di dalam rumah tangga dalam arti kata lain, selama kemurtadan tidak berdampak buruk bagi kehidupan rumah tangga yakni masih rukun, maka perkawinan tetap dapat berlangsung selama salah satu atau salah dua suami istri tidak merasa keberatan atas kemurtadan pasangan.(Pasal $116 \mathrm{KHI})$. Mengenai alasan-alasan perceraian ini dapat dilihat pada pasal 39 (2) UU No.1 Tahun 1974 tentang Perkawinan dan pasal 116 KHI.

Dengan demikian, peraturan hukum tentang perkawinan beda agama di Indonesia dapat terjadi penyelundupan hukum dengan memanipulasi hukum. Pada awalnya pasangan yang akan melangsungkan perkawinan seagama, namun kemudian kembali pada agama semulanya sehingga terjadilah beda agama dalam rumah tangga tersebut.

Meskipun pada nyatanya ditemukan pula dalam pasal 75 KHI yang mengatur tentang pembatalan perkawinan, yang salah satu alasan pembatalannya adalah "salah satu dari suami istri murtad". Ketentuan ini mempunyai dampak bahwa sebuah perkawinan yang salah satu pihaknya murtad akan dibatalkan pernikahannya terhitung sejak putusan dijatuhkan. Jadi, murtadnya seseorang tidak "otomatis" membuat pernikahannya menjadi batal, ia tetap berlangsung dan dipandang sebagai ikatan perkawinan yang sah sampai ada putusan pengadilan yang tidak boleh berlaku surut. Perkawinan juga hanya dapat batal apabila ada 
pihak yang berhak secara hukum untuk mengajukan pembatalan ke pengadilan,yakni: (Karsayuda, 2006:140-141)

Pasal 73 KHI: Yang dapat mengajukan permohonan pembatalan perkawinan adalah: para keluarga dalam garis keturunan lurus ke atas dan ke bawah dari suami atau isteri. Suami atau isteri; Pejabat yang berwenang mengawasi pelaksanaan perkawinan menurut Undang-undang.

Para pihak yang berkepentingan yang mengetahui adanya cacat dalam rukun dan syarat perkawinan menurut hukum Islam dan Peraturan Perundangundangan sebagaimana tersebut dalam pasal 67.

Pembatalan perkawinan karena salah satu pihak suami atau istri murtad tidak termasuk dalam alasan batal atau dapat dibatalkannya suatu perkawinan. Namun batalnya suatu perkawinan dilihat dan dimulai sejak putusan pengadilan Agama mempunyai kekuatan hukum tetap (Karsayuda,2006:141).

Dengan demikian perkawinan hanya batal apabila ada pihak-pihak yang mengajukan pembatalan, apabila tidak ada maka perkawinan tetap sah. Sebagaimana yang dapat ditafsirkan dalam aturan poin pasal $116 \mathrm{KHI}$ tentang alasan perceraian, kemurtadan yang dapat diajukan sebagai alasan perceraian hanya apabila hal tersebut menimbulkan perselisihan di dalam rumah tangga, dalam arti bahwa selagi perkawinan tersebut rukun-rukun saja, maka kemurtadan bukanlah suatu alasan untuk bercerai.

\section{PERKAWINAN BEDA AGAMA DALAM PERATURAN ADMINISTRASI KEPENDUDUKAN (ADMINDUK)}

Di atas telah dijelaskan mengenai problematika aturan hukum yang secara langsung maupun tersirat memberi ruang bagi pelaku nikah beda agama. Pada Yurisprudensi Mahkamah Agung (MA) yaitu putusan MA No. 1400 K/Pdt/1986. 
Putusan tersebut termasuk di antaranya bahwa Kantor Catatan Sipil diperkenankan untuk melangsungkan perkawinan beda agama. Putusan ini bermula pada upaya hukum yang dilakukan Andy Vonny Gani P (perempuan) beragama Islam dan Andrianus Petrus Hendrik Nelwan (Laki-laki) beragama Kristen sebagai pasangan yang hendak melakukan pencatatan perkawinan.

Melalui berbagai pertimbangan bahwa pemohon tidak akan melangsungkan perkawinan secara Islam dalam arti pemohon tidak begitu menghiraukan status agamanya sehingga pasal 8 huruf (f) UU Perkawinan tidak lagi merupakan halangan sehingga atas dasar putusan ini Kantor Catatan Sipil Sebagai satu-satunya instansi yang berwenang untuk melangsungkan atau membantu melangsungkan perkawinan yang kedua calon suami istri tidak beragama Islam wajib menerima permohonan pemohon. (Hukumonline.com, 2014:91-92).

Dari alasan MA dalam memutuskan kebolehan nikah beda agama dilihat dari pemohon yang tidak menghiraukan agamanya, maka timbul pertanyaan peneliti, mengapa pemohon tidak mengganti agamanya supaya pasangan suami istri menjadi seagama jika benar pemohon tidak lagi menghiraukan agama Islam sebagai agama pemohon sehingga jelas alasan untuk sahnya pernikahan beda agama tersebut, ini menunjukkan bahwa meskipun di dalam KTP seseorang beragama Islam namun apabila agama tersebut tidak dikaitkan lagi dengan pernikahan maka meskipun pasangan beda agama maka diperbolehkan untuk melakukan pencatatan nikah dengan dalih tidak menghubungkan agama dengan pernikahan.

Jadi, pada dasarnya meskipun secara ketentuan perundang-undangan nikah beda agama dilarang, namun terdapat kemungkinan-kemungkinan dan peluang 
untuk melangsungkan nikah beda agama, ditambah dengan adanya yurisprudensi MA, pernikahan beda agama di Kantor Catatan Sipil dimungkinkan pula.

Perkawinan beda agama dapat dicatatkan di Kantor Catatan Sipil sebagaimana dikatakan dalam pasal 35 huruf (a) jo. Pasal 34 UU No. 23 Tahun 2006 tentang Administrasi Kependudukan. Dalam pasal tersebut dikatakan bahwa pencatatan perkawinan dalam pasal 34 UU ADMINDUK berlaku juga bagi perkawinan yang ditetapkan oleh pengadilan. Dalam pasal 35 huruf (a) UU Adminduk dikatakan bahwa yang dimaksud dengan perkawinan yang ditetapkan oleh pengadilan adalah perkawinan yang dilakukan antar umat yang berbeda agama (Hukumonline.com, 2014:93).

\section{STATUS HUKUM PELAKSANAAN PERKAWINAN BEDA AGAMA DI INDONESIA}

Undang-undang Perkawinan tidak mengatur tentang perkawinan antar agama. Sebelum berlakunya UU Perkawinan, perkawinan campuran di atur di dalam HOCI dan GHR, di mana pelaksanaannya berdasarkan hukum suami atau istri kalau ada persetujuan untuk itu dan pencatatnnya dilakukan oleh Kantor Catatan Sipil pada daftar perkawinan campuran. (O.S, Eoh, 1996:127). Setelah berlakunya UU Perkawinan, dalam pasal 2 PP No. 09 Tahun 1975, ditentapkan:

Pencatatn perkawinan bagi mereka yang melangsungkan perkawinannya menurut agama Islam dilakukan oleh pegawai pencatatan perkawinan pada KUA.Pencatatan perkawinan bagi mereka yang melangsungka perkawinannya menurut agama dan kepercayaannya selain agama Islam dilakukan oleh Pegawai Pencatatan Perkawinan pada Kantor Catatan Sipil.

Dari uraian peraturan di atas tidak diatur tentang pencatatan perkawinan antar agama. Hal ini karena UU Perkawinan memang tidak mengatur tentang perkawinan antar agama sehingga aturan tentang pencatatan perkawinannyapun 


\section{Jurnal Ilmiah Al-Syir'ah Vol. 16 No. 1 Tahun 2018 Institut Agama Islam Negeri (IAIN Manado)}

tidak diatur. Namun pada tahun 1983 tentang Penataan dan Peningkatan Pembinaan Penyelenggaraan Catatan Sipil, telah meniadakan tugas penyelenggaraan perkawinan yang merupakan kewenangan Kantor Catatan Sipil, sehingga Kantor Catatan Sipil hanya berwenang untuk mencatat kelahiran, perkawinan, dan pengakuan dan pengesahan anak, perceraian dan kematian. Akibat berlakunya Keputusan Presiden tersebut, ada Kantor Catatan Sipil tidak bersedia melangsungkan perkawinan perkawinan antar agama namun ada pula yang mau melangsungkan dan mencatatkan perkawinan antar agama sebagaimana kewengan yang diberikan UU Perkawinan (O.S, Eoh, 1996:128): Pasal 20 menetapkan, Pegawai Pencatatn Perkawinan melangsungkan atau membantu perkawinan; Pasal 21 yang menetapkan, Pegawai Pencatatan Perkawinan akan melangsungkan perkawinan kalau diperintah oleh pengadilan (UU No. 1 Tahun 1974).

Ini jelas bahwa keputusan presiden bertentangan dengan aturan Perundang-undangan uang berlaku yakni UU No. 1 Tahun 1974. Oleh karena itu, keputusan presiden perlu untuk ditinjau kembali demi memberikan kepastian hukum sehingga tidak terjadi perbedaan penafsiran pada setiap Kantor Pencatatan Sipil. Sebagaimana telah dipaparkan di atas bahwa keputusan Presiden No. 12 Tahun1983 bertentangan dengan ketentuan pada pasal 20 dan 21 UUP, dengan demikian maka Kantor Pencatatan Sipil masih tentap mempunyai wewenang untuk melangsungkan atau membantu melangsungkan perkawinan, termasuk perkawinan antar agama. Hal ini tentu bukan tanpa sebab, karena tentang hal ini juga sudah ada: Surat Ketua Mahkamah Agung No. KMA/72/IV/1981 tanggal 20 April 1981 tentang Pelaksanaan Perkawinan Campuran, yang ditujuan kepada Menteri Agama dan Menteri dalam Negeri. Dalam surat ini Mahkamah Agung menganggap bahwa: Perkawinan antar pemeluk agama dan penganut kepercayaan 
terhadap Tuhan yang Maha Esa termasuk perkawinan campuran; Perkawinan di Indonesia diakui sebagai suatu "Staatshuwelijk".

Untuk menghilangkan atau setidak-tidaknya mengurangi adanya perkawinan yang dilakukan secara liar atau diam-diam, serta untuk menjamin adanya kepastian hukum Mahkamah Agung mengharapkan adanya petunjuk pelaksanaan dari Menteri Agama dan Menteri dalam Negeri tentang perkawinan antar agama.

Yurisprudensi Mahkamah Agung No. 1400/K/Pdt/1986, tanggal 20 Januari 1989. Dalam keputusan ini Mahkamah Agung memerintahkan agar Kantor Catatan Sipil DKI Jakarta melangsungkan perkawinan antara Andy Vonny Gani P dengan Petrus Hendrik Nelwan, karena perbedaan agama dari calon suami istri tidak menjadi halangan perkawinan.

Sebenarnya menurut ketentuan pasal 2 UU Perkawinan perkawinan yang hanya dilakukan di Kantor Pencatatan Sipil belum/tidak sah karena tidak dilakukan menurut hukum agama baik yang dianut oleh calon suami maupun istri. (O.S, Eoh, 1996:128-145)

Dalam hal ini Kantor Catatan Sipil hanya mencatat perkawinan kedua calon mempelai dengan tujuan agar mereka tidak hidup bersama di luar perkawinan. Di samping itu, Mahkamah Agung menganggap bahwa perkawinan di Indonesia bersifat staatshuwelijk artinya perkawinan sudah sudah sah apabila sudah memenuhi ketentuan hukum negera sedangkan hal-hal yang menyangkut hukum agama adalah urusan suami istri itu secara pribadi. ( O.S, Eoh, 1996:145).

\section{TINJAUAN SADD DZARI'AT TERHADAP PROBLEMATIKA ATURAN HUKUM PERKAWINAN BEDA AGAMA DI INDONESIA}

Sebagaimana yang telah kita ketahui dari pemaparan tentang aturan hukum perkawinan beda agama dalam perspektif penafsiran Al-Quran, sejarah Islam, dan 


\section{Jurnal Ilmiah Al-Syir'ah Vol. 16 No. 1 Tahun 2018 Institut Agama Islam Negeri (IAIN Manado)}

Peraturan Nikah Beda Agama di Indonesia dari berbagai kaca mata (sudut pandang hukum) bahwa tedapat problematika, di mana dalam Islam pernikahan laki-laki muslim dengan wanita Kristen (Yahudi) diperbolehkan dengan status hukum makruh. Sedangkan di dalam peraturan hukum di Indonesia tidak begitu tegas disebutkan larangan pernikahan beda agama, bahkan terdapat beberapa peraturan yang memberikan ruang (peluang) untuk terjadinya pernikahan beda agama meskipun pada asalnya terdapat kesulitan untuk merealisasikannya, termasuk di antaranya pernikahan laki-laki Islam dengan perempuan non Islam maupun sebaliknya.

Maka dengan alasan problematika hukum tersebut di atas, peneliti menggunakan metode Saad Dzari'at untuk melarang pernikahan beda agama termasuk di antaranya pernikahan laki-laki muslim dengan perempuan non Islam. Yang dimaksud dengan Sadd adz-dzari'ah (menutup jalan) ialah mencegah suatu perbuatan agar tidak sampai menimbulkan al-mafsadah (kerusakan), jika ia akan menimbulkan mafsadah. (Abdul Rahman Dahlan,2010:236)

Asy-Syatibi mengklasifikasikan zariah dari segi hakikat dan akibat kerusakan yang diperkirakan akan terjadi kepada beberapa macam, yang dapat direduksi menjadi beberapa bagian: Pertama, sesuatu yang dilakukan akan berakibat kepada kemafsadatan yang pasti. Kedua, sesuatu yang dilakukan dapat membawa kepada kemafsadatan, tetapi jarang terjadi. Ketiga, sesuatu yang dilakukan pada prinsipnya mengandung keberimbangan antara maslahah dan mafsadah atau fifty-fifty, namun ada indikasi untuk melahirkan dugaan kuat bahwa perbuatan akan membawa kepada kerusakan (al-fasad). Dugaan kuat berdasarkan indikasi ini, dalam pandangan Asy-Syatibi, harus disamakan dengan kepastian, dengan alasan: (1) dugaan kuat dalam hukum-hukum 'amaliyah berlaku sebagaimana yakin (2) ada nash ajaran untuk berhati-hati, dan makna Sadd adz- 


\section{Jurnal Ilmiah Al-Syir'ah Vol. 16 No. 1 Tahun 2018 Institut Agama Islam Negeri (IAIN Manado)}

dzariaah adalah berhati-hati terhadap kerusakan, (3) membolehkan zariah semacam ini berarti membenarkan sikap saling membantu dalam berbuat dosa dan permusuhan dilarang oleh Al-Quran. (Duski Ibrahim,2008:148-149).

Dasar hukum Sadd adz-dzariah dari Al-Quran adalah :

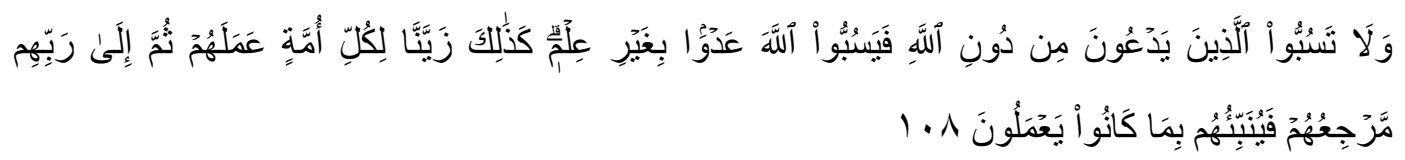

"Dan janganlah kamu memaki sembahan-sembahan yang mereka sembah selain Allah, karena mereka nanti akan memaki Allah dengan melampaui batas tanpa pengetahuan. Demikianlah Kami jadikan setiap umat menganggap baik pekerjaan mereka. Kemudian kepada Tuhan merekalah kembali mereka, lalu Dia memberitakan kepada mereka apa yang dahulu mereka kerjakan.” (Qs. AlAn'am/6: 108).

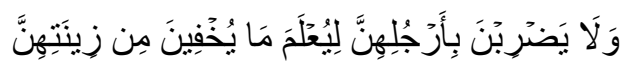

"Dan janganlah mereka memukulkan kakinya agar diketahui perhiasan yang mereka sembunyikan...”(Qs. An-Nur/24 : 31).

Jadi segala sesuatu yang menimbulkan dampak buruk atau dikhawatirkan dengan kemungkinan besar akan berdampak negatif, maka harus dijauhi bahkan ditinggalkan. Perkawinan merupakan ikatan lahir batin yang dalam, kuat, dan kekal antara dua insan, suatu ikatan yang mencakup hubungan timbal balik yang luas antara keduanya, maka tidak boleh tidak, harus dapat kesatuan hati yang dipertemukan dalam suatu ikatan yang tidak mudah dilepas. Untuk itu harus ada kesamaan dasar dan tujuan antara kedua mempelai. 


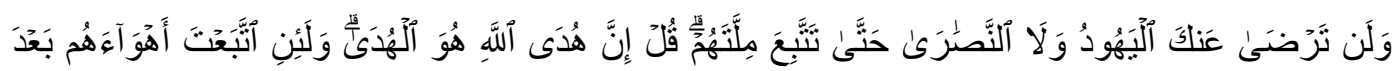

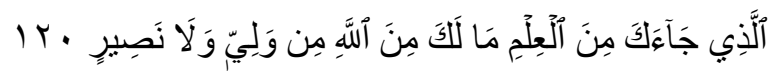

“ Orang-orang Yahudi dan Nasrani tidak akan senang kepada kamu hingga kamu mengikuti agama mereka. Katakanlah: "Sesungguhnya petunjuk Allah itulah petunjuk (yang benar)". Dan sesungguhnya jika kamu mengikuti kemauan mereka setelah pengetahuan datang kepadamu, maka Allah tidak lagi menjadi pelindung dan penolong bagimu”. (Al-Baqarah/2 120)

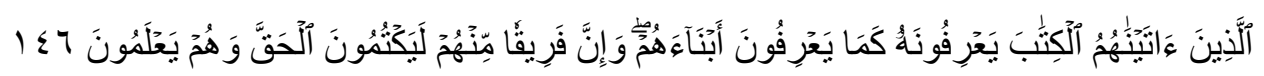

“Orang-orang (Yahudi dan Nasrani) yang telah Kami beri Al Kitab (Taurat dan Injil) mengenal Muhammad seperti mereka mengenal anak-anaknya sendiri. Dan sesungguhnya sebahagian diantara mereka menyembunyikan kebenaran, padahal mereka mengetahui”. (Al-Baqarah /2:146)

Diperbolehkannya menikahi wanita Kitabiyah, jika tidak ada rasa kekhawatiran akan bahaya dan fitnah yang diakibat wanita Ahli Kitab yang hidup di tengah-tengah keluarga muslim yaitu di saat umat Islam sedang jaya sedangkan jumlah wanita muslimah lebih sedikit dibandingkan dengan jumlah lelakinya. Hal ini penah terjadi pada masa penakhlukan kota Mekkah yaitu sekitar tahun ke 9 atau ke $10 \mathrm{H}$. Di mana pada saat itu turun ayat 5 surat Al-Maidah:

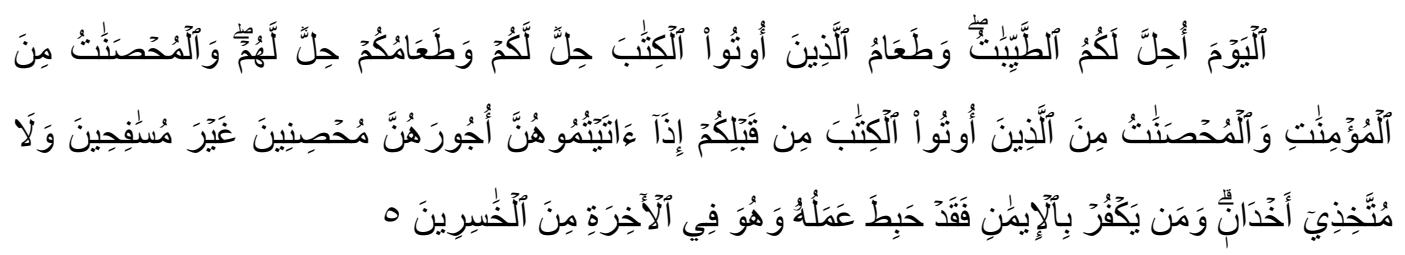

"Pada hari ini dihalalkan bagimu yang baik-baik. Makanan (sembelihan) orangorang yang diberi Al Kitab itu halal bagimu, dan makanan kamu halal (pula) bagi mereka. (Dan dihalalkan mangawini) wanita yang menjaga kehormatan diantara wanita-wanita yang beriman dan wanita-wanita yang menjaga kehormatan di antara orang-orang yang diberi Al Kitab sebelum kamu, bila kamu telah 


\section{Jurnal Ilmiah Al-Syir'ah Vol. 16 No. 1 Tahun 2018 Institut Agama Islam Negeri (IAIN Manado)}

membayar mas kawin mereka dengan maksud menikahinya, tidak dengan maksud berzina dan tidak (pula) menjadikannya gundik-gundik. Barangsiapa yang kafir sesudah beriman (tidak menerima hukum-hukum Islam) maka hapuslah amalannya dan ia di hari kiamat termasuk orang-orang merugi”. (QS. Al-Maidah ayat 5)

Ayat ini menunjukkan bahwa kebolehan menikahi wanita Yahudi (Nasrani) merupakan suatu akibat dari perjuangan Islam di tahap awal di mana wanita muslimah masih berjumlah sedikit sedangkan Islam membutuhkan generasi-generasi baru (keturunan) dan untuk membangun kerjasama sebagai penambah kekuatan dengan cara mendekati wanita dari kelompok ahli kitab yang beriman dan menjaga diri serta berpotensi besar untuk berbalik masuk agama Islam.

Di lihat dari zaman yang semakin maju (modern), pada umumnya seorang pemuda jika sampai menikahi wanita nasrani ataupun Yahudi tentu didorong oleh rasa kasih sayang muda-mudai atau biasa disebut cinta yang menggebu-gebu. Ini ditandai dengan krisis psikologi yang menjadi cinta secara berlebihan hingga memilih wanita non muslim sebagai istri. Rasa cinta yang besar ini dikawatirkan dapat mengalahkan kecintaan kepada Pencipanya yaitu Allah SWT. Sejak zaman dahulu di masa sejarah Timur Tengah hingga saat ini, meskipun zaman sudah modern dan maju pesat, wanita tetap memiliki peran besar dalam pengelolaan rumah tangga termasuk di antaranya sebagai pusat pendidikan anak. Mayoristanya, ikatan batin antara seorang anak dengan ibu yang melahirkannya lebih besar dibandingkan dengan seorang ayah.

Mengawini wanita non muslim dikhawatirkan si suami lebih cenderung mengikuti agama istrinya bila ia amat mencintainya. Boleh jadi anak-anak keurunannya juga akan lebih condong kepada agama ibunya. Dengan demikian 


\section{Jurnal Ilmiah Al-Syir'ah Vol. 16 No. 1 Tahun 2018 Institut Agama Islam Negeri (IAIN Manado)}

suami sebagai seseorang yang beragama Islam mendapatkan imbasnya, sebab suami adalah kepala keluarga (pemimpin) yang bertanggungjawab atas keluarganya di hadapan Allah SWT.

Apabila ditelaah lebih dalam lagi, mengapa para ulama menghukumi makruh menikahi wanita nasrani (Yahudi). Ini tentunya didasarkan pada pertimbangan adanya dalil yang membolehkan, akan tetapi kebolehan menikahi wanita ahli kitab sangat dikhawatirkan dapat menghancurkan rumah tangga dan keyakinan anak-anak maupun keluarga. Sebisa mungkin, Islam menganjurkan untuk menikahi wanita Muslimah, bahkan untuk wanita muslimah pun masih terdapat anjuran untuk memilih wanita shalehah di antara wanita-wanita yang beragama Islam. (Ali Yusuf As-Subki, 2010:40-43)

Sebenarnya, pada asalnya kebolehan menikahi wanita ahli kitab tak terlepas dari tujuan politik, yakni menarik wanita Nasrani (Yahudi) ke dalam agama Islam. (Wahbah Az-Zuhaili, 2011:149) Hal ini menunjukkan terdapat dampak positif dari pernikahan antara pria muslim dengan wanita ahli kita. Akan tetapi perbandingan kemungkinan berhasil sangatlah sulit terlebih apabila faktor cintalah yang membuat seorang lelaki Islam lebih memilih wanita non Islam. Kecenderungan pada rasa cinta dapat melemahkan kebijaksanaan dalam beragama. Terlebih apabila dilihat dalam Qs. Al-baqarah/2: 62, wanita Yahudi maupun Nasrani tidak meyakini Allah SWT, Al-Quran, terlebih untuk beramal shaleh sebagaimana tuntunan Islam.

Sebagai ilustrasi, bagaimana orang-orang Hindu melancarkan serangan gencar untuk menghancur leburkan umat Islam di India, sebagaimana juga mereka melancarkan serangan ekspansi yang ganas terhadap umat Islam di di Kashmir dan Pakistan. Lebih dari itu, mereka telah menjajah Hiderabad yang berpenduduk seratus persen muslim itu dan menghapuskan semua Undang-Undang Islamnya. 


\section{Jurnal Ilmiah Al-Syir'ah Vol. 16 No. 1 Tahun 2018 Institut Agama Islam Negeri (IAIN Manado)}

(Abdul Mutaal Muhammad Al-Jabry, 1988:109) Bahkan Islam saat ini dalam pandangan dunia identik sebagai teroris. Terlebih Israel yang tidak berhenti dengan dendamnya terhadap ummat muslim di Palestina (William G. Carr, 2004:202-204). Begitulah gambaran sejauh mana bahaya orang-orang Kristen dan Yahudi terhadap Islam, terlebih seorang ibu yang beragama kristen tentunya ia memiliki pengaruh yang cukup besar terhadap anak keturunan. Orang tua terutama ibu yang banyak bergulat dengan anak, mempunyai tugas yang amat besar untuk mendidik anak baik pendidikan jasmani, intelektual dan mental spiritual, sehingga melalui teladan yang baik atau pelajaran yang berupa nasehatnasehat, kelak ia dapat memetik tradisi-tradisi yang benar dan pijakan moral yang sempurna dari masa kanakkanaknya (Khairiyah Hasain Thaha,1992:5). Sehingga, seorang ibu yang bukan beragama Islam berpotensi besar mengikuti jejak kepercayaan ibunya.

Tidak bisa dibantah bahwa dampak negatif ini memang benar adanya. Orang yang pernah tinggal di Aljazair, Maroko, dan Tunis umpamanya, akan tau betul sejauh mana bahaya yang bisa dirasakan warga negara di sana yang ibu dan bapaknya berasal dari kolonial Prancis (beragama kristen). Dampak negatif ini merupakan hambatan besar yang dihadapi gerakan kemerdekaandan usaha-usaha Arabisasi. Hambatan ini tentunya disebabkan di sana telah ada generasi-generasi yang menjajahnya dan ibu-ibu mereka yang menganut agama kristen. Bagaimana pula tidak menghambat, sedangkan dari turunan mereka telah lahir anak-anak yang berasal dari turunan Yahudi dan Nasrani (Abdul Mutaal Muhammad AlJabry, 1983:109).

Mempertimbangkan pula di kalangan pasangan yang menikah beda agama, ketika ditanya mengenai kelangsungan akidah anak-anaknya, dengan mudahnya mereka berkata "Kami memeberi kebebasan kepada anak-anak kami untuk 
memilih agamanya kelak" (Tanzil Tanzania, 2010:134). Pendapat demikian sangat tidak lazim keluar dari lidah orang tua. Padahal tugas orang tua tidak terbatas di dunia, tetapi sampai kepada tingkat akhirat, yaitu kepada Allah SWT. (QS. Al-Tahrim/66: 6)

Berdasarkan pertimbangan Sadd Dzari'ah, beberapa dalil-dalil Al-Quran, dan fenomena-fenomena yang dikhawatirkan berpotensi besar merusak keluarga dan generasi (keturunan Islam), maka pernikahan beda agama, termasuk pernikahan antara laki-laki muslim dengan wanita Yahudi (Nasrani) terlarang. Kekhawatiran yang amat besar terhadap mafsadat yang timbul inilah yang menjadi acuan pertimbangan penggunaan Sadd Dzari'ah.

Demikian pula hukum yang terdapat di Indonesia, di lihat dari kacamata dan pertimbangan Sadd Dzari'ah, celah bagi terjadinya pernikahan antara lakilaki muslim dan wanita ahli kitab sebaiknya ditutup rapat.

\section{KESIMPULAN}

Keluarga adalah pendidikan awal bagi anak, pengaruhnya terhadap pola pikir dan tata cara anak dalam bertindak amat besar. Inilah mengapa dikatakan bahwa pengaruh sosial yang amat tinggi adalah keluarga, lingkungan, dan pendidikan informal di dalam sekolah. Ibu adalah anggota keluarga inti yang memiliki peran penting dalam keluarga, termasuk pendidikan anak.

Umumnya, ikatan batin antara seorang anak dengan ibu lebih besar dibandingkan dengan ayah sebab ibulah yang melahirkan si anak. Berdasarkan atas pertimbangan bahwa peran ibu amat sangat berpengaruh, maka di lihat dari metode Saad Dzari'ah, maka pernikahan antara lelaki muslim dengan wanita non muslim (ahli kitab Yahudi dan Nasrani) sebisa mungkin ditiadakan.

Indonesia adalah negara yang memberlakukan banyak peraturan yang mengatur tentang keluarga Islam. Namun tidak ada kalimat tegas dalam peraturan 


\section{Jurnal Ilmiah Al-Syir'ah Vol. 16 No. 1 Tahun 2018 \\ Institut Agama Islam Negeri (IAIN Manado)}

bahwa pernikahan beda agama benar-benar terlarang dan melawan hukum. Buktinya, hanya Kompilasi Hukum Islam yang menyebutkan bahwa perkawinan beda agama tidak diperbolehkan, sementara kedudukan KHI hanyalah instruksi Presiden (kompilasi) bukan Undang-undang yang berkekuatan mengikat kuat. Artinya, bahwa pernikahan beda agama masih dimungkinkan untuk terjadi meskipun pada kenyataannya mengalami kesulitan untuk merealisasikannya.

Sebenarnya pernikahan pria muslim dan wanita Nasrani (Yahudi) meskipun pada hukum asalnya diperbolehkan, namun melihat kepada mafsadat yang berpotensi besar akan timbul apabila terlaksana, maka pernikahan semacam ini dilarang. Pertimbangan atas kekhawatiran besar terhadap dampak negatif yang akan timbul inilah dinamakan Sadd Dzari’ah.

\section{BIBLIOGRAPHY}

Mardani. (2011).Hukum Perkawinan Islam. Yogyakarta: Graha Ilmu.

Mahmood. Tahir. (1987). Personal Law in Islamic Countries. New Delhi: Academy of Law and Religion.

Nuruddin. Amir dan Azhari Akmal Tarigan. (2004). Hukum Perdata Islam di Indonesia. Jakarta: Kencana.

Thalib. Sayti. (1985). Receptie a Contrario. Jakarta: Bumi Aksara.

Sabiq. As-Sayyid. (1983). Fiqh As-Sunnah. Beirut: Dar-Al-Fikr. cet. Keempat. jilid 2.

Az-Zuhaili. Wahbah. (1989). Al-Fiqh Al-Islami wa Adillatuh. Damaskus: Dar AlFikr. cet. Ketiga. jilid 7.

Instruksi Presiden RI.No. 01 Tahun 1991. (2001). Kompilasi Hukum Islam di Indonesia. Jakarta: Direktorat Pembinaan Badan Peradilan Agama Islam Departemen Agama Islam RI.

Wahyuni. Sri. (2016). Nikah Beda Agama Kenapa ke Luar Negeri?. Jakarta: PT Pustaka Alvabet.

Karsayuda. (2006). Perkawinan Beda Agama Menakar Nilai-nilai Keadilan Kompilasi Hukum Islam. Yogyakarta: Total Media Yogyakarta.

Hukumonline.com. (2014). Tanya Jawab tentang Nikah Beda Agama Menurut Hukum di Indonesia. Tangerang: Literasi.

Eoh. O.S. (1996). Perkawinan Antar Agama. Jakarta: RajaGrafindo Persada.

Dahlan. Abdul Rahman. Ushul Fiqh. Jakarta: Amzah. (2010).

Ibrahim. Duski. (2008). Metode Penelitian Hukum Islam. Yogyakarta: Ar Ruzz Media.

Umar. Muin. dkk. (1985). Ushul Fiqh I. Jakarta: Direktorat Jendral Pembinaan Kelembagaan Agama Islam Departemen Agama RI.

As-Subki. Ali Yusuf. (2010). Fiqh Keluarga Pedoman Berkeluarga dalam Islam. Jakarta: Amzah. 
Az-Zuhaili. Wahbah. (2011). Al-Fiqh Al-Islami wa Adillatuh. Jakarta: Gema Insani. cet. Kesepuluh. jilid 9.

Al-Jabry. Abdul Mutaal Muhammad. (1988). Perkawinan Campuran Menurut Pandangan Islam. Jakarta: Bulan Bintang.

Tanzania. Tanzil. (2010). Stop Kristenisasi : Membongkar Gerakan Pemurtadan dan Mencari Solusi Menghadapi Program Kristenisasi. tt:Al-Fajr Media.

Carr. William G. (1991). Yahudi Menggenggam Dunia. Jakarta: Pustaka AlKautsar. 